\title{
Observations on the laboratory culture of the harpacticoid copepod Euterpina acutifrons (Dana, 1847) using different diets
}

\author{
S. JASMINE, RANI MARY GEORGE AND S. LAZARUS* \\ Vizhinjam Research Centre of ICAR-Central Marine Fisheries Research Institute, Vizhijam \\ Thiruvananthapuram - 695 521, Kerala, India \\ *Institute for Coastal Area Studies, Manonmaniam Sundaranar University, Scott Christian College Campus \\ Nagercoil, Kanyakumari - 629 003, Tamil Nadu, India \\ e-mail:jasminevzm@rediffmail.com
}

\begin{abstract}
Hatching success, nauplii production, maturation and survival of the harpacticoid copepod Euterpina acutifrons (Dana, 1847) fed on mono/mixed culture of Isochrysis galbana, Tetraselmis gracilis, Chaetoceros calcitrans and Chlorella marina were studied. The time taken for E. acutifrons to mature was the lowest with a diet of $I$. galbana followed by C. calcitrans. Percentage of survival was highest with a mixed diet of $75 \%$ I. galbana and $25 \%$ C. calcitrans ( $84 \%$ ) followed by $T$. gracilis (68\%). The study also revealed that both feed type and concentration played significant role in production and survival of E. acutifrons. Mixed diet of I.galbana and C. calcitrans showed maximum adult production followed by a diet of T.gracilis. The mean values of all the three stages of the copepod viz., adults, ovigerous females and copepodite-nauplii were found much greater in the treatment with replacement of the culture medium and feed. Mass culture using different organic feeds was also carried out and it was found that mean growth in terms of adult stage production was found to be higher when fed with rice bran followed by groundnut oil cake (GOC) and the least in cow dung treatment. In rice bran treatment, copepodites showed higher production rate when compared to the other two feeds. Mean growth in terms of nauplii production was also higher in rice bran fed group followed by GOC fed group and the least in cow dung treatment.
\end{abstract}

Keywords: Algal feeds, Artificial feed, Copepod culture, Harpacticoid copepod, Euterpina acutifrons, Mass culture, Population density

\section{Introduction}

Production of marine copepods in the hatchery is important for solving feed related problems in the rearing of marine fin fish larvae. Copepods have been used for marine fish species, which normally do not accept artificial feeds. Therefore in recent years, much attention has been focused on mass culture of copepods under laboratory and hatchery conditions. Attempts on mass culture of different species of copepods have been carried out worldwide (Stottrup and Norsker, 1997; Nanton and Castell, 1998; Schipp et al., 1999; Payne and Rippingale, 2000; Stottrup, 2000 ) in view of their worldwide distribution, abundance, high rate of reproduction, short generation time, high nutritive value and smaller naupliar stages. Gopakumar et al. (2008) gave an account on mixed culture of the harpacticoid species Euterpina acutifrons (Dana, 1847) and the calanoid copepod Psuedodiaptomus sericaudatus as live feed for ornamental fish larval rearing.

There is great interest in culturing harpacticoid copepods since they have smaller naupliar stages, high reproductive potential, fast population growth, flexible diet and tolerance to wide ranges of environmental factors such as temperature and salinity (Sun and Fleeger, 1995; Stottrup and Norsker, 1997). Moreover, harpacticoid copepods provide a broad spectrum of prey sizes suitable for developing fish larvae, help to keep the walls of the fish larval rearing tanks clean by grazing on algae and debris (Delbare et al., 1996) and are also rich in essential fatty acids that are extremely important for larval fish survival and growth (Stottrup and Norsker, 1997). Nassogne (1970) and Kraul (1990) have reported on culture of E. acutifrons. The culture conditions for harpacticoids are less demanding than those for calanoids. Filtered seawater may be used and a whole range of inert food is acceptable to many harpacticoid species. This simplifies the culture method and eliminates the need for culture of phytoplankton.

E. acutifrons is a holoplanktonic suspension feeding copepod which is a common species in coastal waters off Vizhinjam. It is a hardy species and easy to maintain in laboratory conditions. In the present study, an attempt was made to investigate the diets that will improve production of $E$. acutifrons under laboratory conditions using different algal feeds as well as selected inert feeds. 


\section{Materials and methods}

The marine harpacticoid copepod E. acutifrons was collected from Vizhinjam Bay. Copepods were cultured on marine algae with continuous aeration at room temperature, at $35 \mathrm{ppt}$ salinity. Four algal species each with specific nutritional characteristics, viz., Isochrysis galbana, Tetraselmis gracilis, Chaetoceros calcitrans and Chlorella marina in monoculture as well as in combinations i.e., I. galbana plus C. calcitrans, T. gracilis plus I. galbana and C. calcitrans plus I. galbana were fed to copepods to elucidate the ideal algal feed for culture. Algal cultures at the required density were prepared by counting samples using a haemocytometer, followed by dilution using enriched seawater. Initial trials were carried out to evaluate development and survival using different algae to find out the most suitable feed. Ten millilitre capacity glass vials were used for the experiment to test different algal concentrations viz., $1 \times 10^{6}, 2 \times 10^{6}, 3 \times 10^{6}$, $5 \times 10^{6}$ and $6 \times 10^{6}$ cells $\mathrm{ml}^{-1}$. Newly hatched nauplii were daily picked out of the experimental vials with a Pasteur pipette and counted. The animals were transferred to new vials with appropriate algal concentration on every third day. Experiments were carried out until next generation of ovigerous copepods were obtained.

Mass culture experiments of copepods were done employing the ideal concentration arrived at during the initial vial experiment for each microalga. Ovigerous females were stocked in $1000 \mathrm{ml}$ glass beakers containing the following algae: Group I - Chlorella marina; Group IIChaetoceros calcitrans; Group III - Isochrysis galbana; Group IV - Tetraselmis gracilis and Group V - Mixed culture of I. galbana and C. calcitrans.

Twenty ovigerous females were stocked in glass beakers containing 1 litre of the respective microalgal culture. Three beakers were assigned to each diet group. Algal culture was separately maintained for feeding the copepods and desired concentration was obtained through centrifugation and dilution. Gentle aeration was maintained via an open glass capillary tube. Two sets of experiments were conducted, in the first set media and algae were not changed during the experimental period. In the second set, $50 \%$ of medium was replaced and filled with water containing fresh algae on alternate days. Counts were taken on alternate days from $5 \mathrm{ml}$ sample collected from the well stirred beaker. Copepod population density (no. per $1000 \mathrm{ml}$ ) was noted and counts were taken separately for nauplii, copepodites, adults and ovigerous females.

Another set of experiment was conducted in 5 litre transparent plastic buckets (in triplicates) using organic material as source of feed. Cow dung, groundnut oil cake (GOC) and rice bran in combination with urea and superphosphate were used to prepare culture media. For each $100 \mathrm{~g}$ of prime component, $0.5 \mathrm{~g}$ urea and $2 \mathrm{~g}$ superphosphate were added. Dry cow dung was powdered and again dried in oven for $24 \mathrm{~h}$. This was used for preparing the medium in filtered seawater. Rice bran and GOC were collected from the local market and dried in the oven and a suspension was prepared by soaking in filtered seawater. The culture media were inoculated with known numbers of $E$. acutifrons. The culture was maintained for a period of four weeks with continuous aeration. The rearing water quality parameters were maintained at optimal levels, i.e., temperature $-28 \pm 0.5^{\circ} \mathrm{C}$, salinity - $35 \%$ o and $\mathrm{pH}-8$ to 8.2 . In all the culture groups, copepod count (no. per $1000 \mathrm{ml}$ ) was taken at weekly intervals.

\section{Results}

Results of the study indicated that the feed type and concentration played a significant role in the survival of E. acutifrons (Table 1). The time taken for the animals to mature was significantly shorter $(\mathrm{p}<0.01)$ with a diet of I. galbana (6 days) at a concentration of $1 \times 10^{6}$ cells $\mathrm{ml}^{-1}$ and with mixed diet of I. galbana and C. calcitrans (7 days). Time to maturity was comparatively higher with C. calcitrans ( 9 days) at an optimum cell concentration of $2 \times 10^{6}$ cells $\mathrm{ml}^{-1}$ and $C$. marina (9 days) at a cell concentration of $6 \times 10^{6}$ cells $\mathrm{ml}^{-1}$. Copepods fed with T. gracilis took the longest time to mature (10 days) at a concentration of $1 \times 10^{6}$ cells $\mathrm{ml}^{-1}$, but the best survival rate was observed in this feed. The highest percentage of survival was observed with mixed diet of $75 \%$ I. galbana and $25 \%$ C. calcitrans $(84 \%)$ on the $7^{\text {th }}$ day followed by $T$. gracilis $(68 \%)$ on $10^{\text {th }}$ day, a mixed diet of $75 \%$ C. calcitrans and I. galbana $25 \%(61 \%)$ on $7^{\text {th }}$ day, C. calcitrans $(50 \%)$ on $9^{\text {th }}$ day, I. galbana $(41 \%)$ on $6^{\text {th }}$ day and $C$. marina $(27 \%)$ on $9^{\text {th }}$ day (Table. 1$)$.

The mass culture experiments conducted in 1 litre glass beakers showed that the food for copepod growth is stage-specific i.e., requirements of feed differ with developmental stage. In the first set, without replacement of culture medium and algae, group $\mathrm{V}$ with mixed diet of I. galbana and C. calcitrans showed maximum adult production followed by group IV diet of $T$. gracilis (Table 1). Group II showed least performance with respect to adult production and growth. Analysis of variance along with post-hoc analysis showed highly significant difference among different treatments $(\mathrm{p}<0.01)$. Performance of group IV and V did not differ significantly. Similarly group I and II also performed equally with respect to adult production and growth. In the mass culture experiment without replacement of culture medium, maximum density for adults was observed in group IV (119.67 nos. $1^{-1}$ ) and minimum in group II (39.33 nos. $\mathrm{l}^{-1}$ ) 
Table 1. Hatching success, nauplii production, time to maturity and survival of Euterpina acutifrons fed on different algal diets

\begin{tabular}{|c|c|c|c|c|c|}
\hline Algal species & $\begin{array}{l}\text { Algal concentration } \\
\left(\mathrm{x} 10^{6} \text { cells ml }{ }^{-1}\right)\end{array}$ & $\begin{array}{l}\text { Number of nauplii } \\
(\text { Mean } \pm \text { SD) }\end{array}$ & $\begin{array}{l}\text { Number of adults } \\
\text { with eggs (Mean } \pm \text { SD) }\end{array}$ & $\begin{array}{l}\text { Time to maturity } \\
\text { (days) }\end{array}$ & $\%$ Survival \\
\hline \multirow[t]{3}{*}{ Chaetoceros calcitrans } & 1 & $18 \pm 2$ & $3 \pm 2$ & 14 & $17 \pm 0$ \\
\hline & 2 & $32 \pm 4$ & $16 \pm 5$ & 09 & $50 \pm 1$ \\
\hline & 3 & $18 \pm 3$ & $2 \pm 1$ & 12 & $11 \pm 1$ \\
\hline \multirow[t]{4}{*}{ Isochrysis galbana } & 0.5 & $10 \pm 1$ & 0 & - & 0 \\
\hline & 1 & $34 \pm 1$ & $14 \pm 2$ & 06 & $41 \pm 1$ \\
\hline & 2 & $26 \pm 4$ & 0 & - & 0 \\
\hline & 3 & $13 \pm 2$ & 0 & - & 0 \\
\hline \multirow[t]{4}{*}{ Tetraselmis gracilis } & 0.5 & $10 \pm 1$ & 0 & - & 0 \\
\hline & 1 & $25 \pm 2$ & $17 \pm 3$ & 10 & $68 \pm 1$ \\
\hline & 2 & $17 \pm 3$ & 0 & - & 0 \\
\hline & 3 & $13 \pm 2$ & 0 & - & 0 \\
\hline \multirow[t]{2}{*}{ Chlorella marina } & 5 & $11 \pm 1$ & 0 & - & 0 \\
\hline & 6 & $11 \pm 2$ & $3 \pm 1$ & 09 & $27 \pm 1$ \\
\hline C. calcitrans $(25 \%)+$ I. galbana $(75 \%)$ & $1+2$ & $37 \pm 3$ & $31 \pm 3$ & 07 & $84 \pm 0$ \\
\hline C. calcitrans $(75 \%)+$ I. galbana $(25 \%)$ & $1+2$ & $23 \pm 3$ & $14 \pm 4$ & 07 & $61 \pm 1$ \\
\hline C. calcitrans $(50 \%)+$ I. galbana $(50 \%)$ & $1+2$ & $33 \pm 3$ & 0 & - & 0 \\
\hline
\end{tabular}

Table 2. The maximum mean density of ovigerous females was obtained in group II (30.33 nos. $\left.1^{-1}\right)$ and minimum in group III. Maximum density of the early stages such as nauplii and copepodites were recorded in Group III (136.33 nos. $\left.1^{-1}\right)$ and minimum in group I (49.33 nos. $\left.\mathrm{l}^{-1}\right)$.

In the mass culture experiment with replacement of culture medium, group $\mathrm{V}$ with mixed diet of I. galbana and $C$. calcitrans showed maximum production followed closely by group IV and III (Table 3) as observed without replacement of culture medium. Lowest density

Table 2. Production of different stages of E. acutifrons in mass culture experiment using different algal diets, without replacement of culture medium

\begin{tabular}{|c|c|c|}
\hline \multirow{2}{*}{ Stage } & \multirow{2}{*}{ Group } & Density (no. $1^{-1}$ ) \\
\hline & & Mean \pm SD \\
\hline \multirow[t]{5}{*}{ Adults } & $\mathrm{I}($ C. marina $)$ & $40.33 \pm 5.50^{\mathrm{a}}$ \\
\hline & II (C. calcitrans) & $39.33 \pm 7.00^{\mathrm{a}}$ \\
\hline & III (I. galbana) & $79.67 \pm 21.50^{b}$ \\
\hline & IV (T. gracilis) & $119.67 \pm 12.38^{\mathrm{c}}$ \\
\hline & V (Mixed) & $131.33 \pm 14.76^{c}$ \\
\hline \multirow[t]{5}{*}{ Ovigerous females } & I (C. marina $)$ & $13.00 \pm 6.25^{\mathrm{a}}$ \\
\hline & II (C. calcitrans $)$ & $30.33 \pm 13.00^{\mathrm{b}}$ \\
\hline & III (I. galbana) & $13.33 \pm 2.18^{\mathrm{a}}$ \\
\hline & IV (T. gracilis) & $14.00 \pm 1.50^{\mathrm{a}}$ \\
\hline & V (Mixed) & $24.67 \pm 2.50^{\mathrm{b}}$ \\
\hline \multirow[t]{5}{*}{ Copepodites+Nauplii } & $\mathrm{I}($ C. marina $)$ & $49.33 \pm 31.43^{\mathrm{a}}$ \\
\hline & II (C. calcitrans) & $62.00 \pm 42.00^{\mathrm{a}}$ \\
\hline & III (I. galbana) & $136.33 \pm 15.98^{b}$ \\
\hline & IV (T. gracilis) & $122.33 \pm 10.58^{\mathrm{b}}$ \\
\hline & V (Mixed) & $129.00 \pm 15.87^{b}$ \\
\hline
\end{tabular}

$\overline{\text { Values bearing same superscripts within each stage do not differ significantly }}$ $(\mathrm{p}<0.01)$
Table 3. Production of different stages of E. acutifrons in mass culture experiment using different algal diets, with replacement of culture medium

\begin{tabular}{|c|c|c|}
\hline \multirow{2}{*}{ Stage } & \multirow{2}{*}{ Group } & Density (no. ${ }^{-1}$ ) \\
\hline & & Mean \pm SD \\
\hline \multirow[t]{5}{*}{ Adults } & $\mathrm{I}($ C. marina $)$ & $68.00 \pm 6.54^{\mathrm{a}}$ \\
\hline & II (C. calcitrans) & $74.67 \pm 5.89^{\mathrm{a}}$ \\
\hline & III (I. galbana) & $159.67 \pm 21.50^{\mathrm{b}}$ \\
\hline & IV (T. gracilis) & $164.00 \pm 15.32^{\mathrm{b}}$ \\
\hline & V (Mixed) & $187.00 \pm 4.33^{\mathrm{c}}$ \\
\hline \multirow[t]{5}{*}{ Ovigerous females } & I (C. marina $)$ & $19.33 \pm 2.18^{\mathrm{a}}$ \\
\hline & II (C. calcitrans) & $45.00 \pm 4.82^{\mathrm{c}}$ \\
\hline & III (I. galbana) & $28.67 \pm 7.86^{b}$ \\
\hline & IV (T. gracilis) & $18.33 \pm 2.78^{\mathrm{a}}$ \\
\hline & V (Mixed) & $57.00 \pm 3.12^{\mathrm{d}}$ \\
\hline \multirow[t]{5}{*}{ Copepodites + Nauplii } & $\mathrm{I}($ C. marina $)$ & $73.67 \pm 23.52^{\mathrm{a}}$ \\
\hline & II (C. calcitrans) & $98.67 \pm 20.35^{b}$ \\
\hline & III (I. galbana) & $221.00 \pm 30.01^{\mathrm{d}}$ \\
\hline & IV (T. gracilis) & $154.67 \pm 7.86^{\mathrm{c}}$ \\
\hline & V (Mixed) & $158.00 \pm 12.22^{\mathrm{c}}$ \\
\hline
\end{tabular}

Values bearing same superscripts within each stage do not differ significantly $(\mathrm{p}<0.01)$

was encountered in group I and II. Analysis of variance along with post-hoc analysis showed highly significant difference among different treatments $(\mathrm{p}<0.01)$. Group III and IV performed almost equally with not much difference. Similarly group I and II also performed equally with respect to adult production. Group V as well as group II showed maximum production and growth with respect to ovigerous stage in the first set without replacement of feed. Among the others, group III gave better output than I and IV. In the second set with replacement of feed, production of copepodites and nauplii was maximum in group III 
followed by group V and IV. All these three groups did not differ significantly as indicated by Duncan's multiple range post-hoc analysis. Group I and II showed poor performance compared to other three groups with much low values (Table 2 and 3 ).

The paired samples analysis was done group-wise in both treatments. In all the groups, mean density of all the three stages of animals viz., the adults, ovigerous females and copepodites+nauplii were found to be significantly higher $(p<0.01)$ in treatment with replacement of culture media and feed. The algal concentration was found to have more significant effect $(p<0.01)$ on the mean density of different stages of copepods.

In the mass culture experiment employing organic inert feeds, adult stage production was found to be significantly higher $(p<0.01)$ in treatment III (rice bran fed copepods) followed by treatment II (GOC fed copepods) and least in cow dung treatment (Table 4). The adults registered a similar growth pattern in all the treatment groups during the first week. During the second week, a sharp decline was noticed in treatment II and III. In treatment III, further growth was observed in the second week which then started to decline. Ovigerous female production was found higher in rice bran fed population followed by GOC fed copepods in treatment II and least in cow dung treatment (Table 4). Production of copepodites also registered almost the same production pattern as of adults. In rice bran treatment, copepodites showed a higher production rate when compared to the other two feeds (Table 4). But unlike in adults, a sharp decline was noticed initially in all the three diets which thereafter registered a steady growth. Nauplii production was also found to be higher in treatment III fed with rice bran followed by GOC fed treatment II, with least production in cow dung treatment (Table 4). The nauplii registered similar growth pattern during the first week except in cow dung treatment, which showed a steady stage. Then it declined and again after third week registered a slight increase in number. In treatment II and III, after first week, a steady decline was noticed.

\section{Discussion}

Feed type and concentration play vital role in the reproductive responses of copepods. The amount of food supplied directly influences their reproductive rate. It is evident that food type, size and concentration can independently as well as in combination influence the reproductive potential and hatching, growth rate, development and survival time to maturity of the copepod population. In the first experiment in vials $(10 \mathrm{ml})$ hatching success, nauplii production, time to maturity and percentage of survival of E. acutifrons mainly depended on diet. The hatching success and percentage survival were highest with a mixed diet of $75 \%$ I. galbana and $25 \%$ C. calcitrans. The observations by Shrivastava et al. (1999) is in agreement with our findings, wherein they concluded that the combined feed of I. galbana and Chaetoceros sp. to be most satisfactory for the estuarine calanoid copepod Heliodiaptomus cinctus. Nassogne (1970) reported that the best results were obtained when E. acutifrons was fed with a mixture of algal species. In the present study, the time to maturity for E. acutifrons, was shortest with a diet of I. galbana, followed by C. calcitrans, C. marina and T. gracilis. Similarly Payne and Rippingale (2000) recorded highest egg production in the calanoid copepod Gladioferens imparipes on a diet of I. galbana followed by C. calcitrans. As in the present

Table 4. Production (Mean \pm SD) of different stages of E. acutifrons in mass culture experiment using different organic feed inputs

\begin{tabular}{llllll}
\hline Stage & Treatment & Day 7 & Day 14 & Day 21 & Day 28 \\
\hline Ovigerous females & I & $1.00 \pm 0^{\mathrm{b}}$ & $1.50 \pm 0.55^{\mathrm{a}}$ & $1.00 \pm 0^{\mathrm{a}}$ & $1.00 \pm 0^{\mathrm{b}}$ \\
& II & $0.50 \pm 0.55^{\mathrm{a}}$ & $1.00 \pm 0^{\mathrm{a}}$ & $1.00 \pm 0^{\mathrm{a}}$ & $0.50 \pm 0.55^{\mathrm{a}}$ \\
& III & $1.00 \pm 0^{\mathrm{b}}$ & $1.50 \pm 0.55^{\mathrm{a}}$ & $1.50 \pm 0.55^{\mathrm{b}}$ & $1.00 \pm 0^{\mathrm{b}}$ \\
\hline Adults & I & $6.50 \pm 1.64^{\mathrm{a}}$ & $8.00 \pm 1.1^{\mathrm{a}}$ & $4.50 \pm 0.55^{\mathrm{a}}$ & $2.50 \pm 0.55^{\mathrm{a}}$ \\
& II & $6.50 \pm 0.55^{\mathrm{a}}$ & $8.50 \pm 0.55^{\mathrm{a}}$ & $6.50 \pm 1.64^{\mathrm{a}}$ & $3.50 \pm 0.55^{\mathrm{b}}$ \\
\hline Copepodites & III & $8.50 \pm 0.55^{\mathrm{b}}$ & $8.50 \pm 1.64^{\mathrm{a}}$ & $11.50 \pm 2.74^{\mathrm{b}}$ & $7.00 \pm 1.1^{\mathrm{c}}$ \\
\hline Nauplii & I & $7.50 \pm 0.55^{\mathrm{a}}$ & $22.50 \pm 4.93^{\mathrm{a}}$ & $14.50 \pm 2.74^{\mathrm{a}}$ & $10.00 \pm 1.1^{\mathrm{a}}$ \\
& II & $10.00 \pm 1.1^{\mathrm{b}}$ & $26.50 \pm 1.64^{\mathrm{b}}$ & $13.50 \pm 4.93^{\mathrm{a}}$ & $11.00 \pm 1.1^{\mathrm{a}}$ \\
& III & $15.00 \pm 1.1^{\mathrm{c}}$ & $47.00 \pm 0^{\mathrm{c}}$ & $15.50 \pm 4.93^{\mathrm{a}}$ & $14.00 \pm 1.1^{\mathrm{b}}$ \\
\hline
\end{tabular}

Treatment I - Cowdung; Treatment II - GOC; Treatment III - Rice bran. Values bearing same superscripts within each stage do not differ significantly $(\mathrm{p}<0.01)$ 
work, Stottrup and Jensen (1990) recorded higher egg production in Acartia tonsa on a diet of I. galbana. The fatty acid profile of algae used in copepod diets (Payne and Rippingale, 2000) showed that I. galbana had a high DHA:EPA ratio and this may be the reason for the use of I. galbana for sustained viable egg production through multiple generations of copepod species. After I. galbana, C. calcitrans was found to the next beneficial diet for culture of E. acutifrons in the present study. Copepods fed on I. galbana tended to have shorter time for maturity than those fed on T. gracilis. The present study is in conformity with the studies made by Payne and Rippingale (2000) wherein they found I. galbana as the second best diet for G. imparipes. C. marina, resulted in poor hatching and survival to maturity. However, a mixture of the best two diets I. galbana and C. calcitrans showed good hatching, survival and egg production within 7 days. Miralto et al. (2005) studied the effect of food type (two diatoms and two dinoflagellates) on the egg production and hatching success of Centropages typicus. Reproductive responses were strongly affected by food type and fecundity was twice high with larger cells and hatching success was 2-3 times higher with dinoflagellate diets.

In the mass culture experiments with algal diets, adult production and survival were higher with a mixed diet of $75 \%$ I. galbana and $25 \%$ C. calcitrans, in both set of experiments with and without replacement of culture medium and algae. This is in agreement with earlier referred works of Shrivastava et al. (1999) and Nassogne (1970). Robin et al. (2005) reported that ChaetoerosIsochrysis combination enabled favourable production of Paracalanus sp. Schipp et al. (1999) similarly reported benefit of using mixed algal diet for mass production of Acartia sp. Corkett and Urry (1968) reported that I. galbana and the diatom Lauderia borealis were the most satisfactory food organisms for Paracalanus elongates. The second best feed which produced more adults was $T$. gracilis in place of I. galbana. The survival rate was in agreement with the initial glass vial experiments. Similar observation was reported by Huei-Meei Su et al. (2005) in the production of Apocyclops royi. When fed with Tetraselmis sp., A. royi matured earlier and produced more offsprings, than copepods fed with other 10 diets. Copepods fed on Tetraselmis sp., which contains low amount of eicosapentaenoic acid (EPA) and no docosahexaenoic acid (DHA) grew faster than I. galbana which is rich in DHA indicating that the highly unsaturated fatty acid content may not be critical in the growth of $A$. royi. Same may be true in the case of E. acutifrons also. The growth pattern may change in mass culture depending on the population size, concentration and size of feed. The positive effect of I. galbana was also observed in several studies worldwide. Similarly, in copepodite and nauplii production also, I. galbana was observed to be the best feed than the mixed diet and T. gracilis. The findings illustrate a stage specific microalgal requirement of the copepod, with smaller developmental stages of $E$. acutifrons benefiting from I. galbana diet and adults favouring $T$. gracilis diet. It is in line with the findings of David et al. (2005) where Chaetoceros proved to be an inferior diet to Isochrysis for nauplii. Several studies have reported high survival rates and fecundity among adult copepods offered with large celled microalgae (Murray and Marcus, 2002; McKinnon et al., 2003). Adults seemed to prefer comparatively large celled T. gracilis to I. galbana and mixed diet. Microalgal size is an important factor affecting feeding efficiency of different copepod developmental stages (Berggreen et al., 1988). In the present study, it was found that the size of food organisms also influenced the growth and biomass of $E$. acutifrons. Similar results were earlier recorded by Nassogne (1970) in E. acutifrons and Corkett (1970) in Acartia tonsa.

With respect to ovigerous females, comparatively good production was noticed with $C$. calcitrans and mixed algal diet. In all other diet treatments, almost same rate of production was noticed. Razouls et al. (1986) reported that cell size is an important factor affecting production of Temora stylifera. In all the treatment groups, production of all the three stages viz., adults, ovigerous females and copepodites-nauplii was found to be much higher with replacement of culture medium. Comparatively low production in the second set without replacement of culture medium, could be attributed to the inadequate feed in the medium. Food is an important limiting factor to support the growth and density of copepod in laboratory culture. The abundance of nauplii, copepodites and adults of $E$. acutifrons increased in proportion to the increased food concentration throughout the culture. Guisande et al. (1996) observed that if the food concentration in the food column diminished, mean number of eggs also decreased, resulting in lower production of next generation.

In the mass culture trials using organic feed medium, almost similar pattern was observed in the production of adults, ovigerous females, copepodites and nauplii. Rice bran proved to be the best for copepod production, followed by groundnut oil cake with cow dung showing the lowest production. Turk et al. (1982) described rice bran culture as a simple, inexpensive and successful method for production of $A$. tonsa and successfully cultured the population for four months in seawater with rice bran. He opined that it provides all the nutrients for the copepods. Vilela (1992) reported that the caloric content and nutritional quality was better in rice bran-Platymonas mix for culture of Tigriopus brevicornis. 
Barber and Barber (1974) established that rice bran contained many important amino acids and vitamins which are of high nutritive value. Joebert et al. (2005) reported that the decreasing trend in copepod production in the second week onwards could be due to predation or cannibalism. In the present study, 14 days of culture was found to be optimal under laboratory conditions. The candidate species $E$. acutifrons had a generation time of 10-14 days, which depend on the temperature and availability of food. The maximum production of nauplii was attained on $14^{\text {th }}$ day of culture and the production decreased from $15^{\text {th }}$ day onwards during most of the experimental trials.

\section{Acknowledgements}

The authors are grateful to Dr. Kurian Mathew Abraham, Asst. Professor, Department of Zoology, Mar Thoma College, Thiruvalla, Kerala, for his assistance in the statistical analyses and preparation of the manuscript.

\section{References}

Barber, S. and Benedito De Barber, B. 1974. Basic and applied research needs for optimising utilisation of rice bran as food and feed. In: Barber, S. and Tortoso, E. (Eds.), Proceedings of the Rice byproducts utilisation, International Conference, vol. 4. Rice bran utilisation food and feed, Institute de agroguimicay technologia de alimentos, Valencia, Spain, p.1-99.

Berggreen, U., Hansen, B. and Kiorboe, T. 1988. Food size spectra, ingestion and growth of the copepod Acartia tonsa during development: Implications for determination of copepod production. Mar. Biol., 99: 341-52.

Corkett, C. J. 1970. Techniques for breeding and rearing calanoid copepods. Helgolander Wiss. Meeresunters, 20: 333-345.

Corkett, C. J. and Urry, D. L. 1968. Observations on the keeping of adult female Pseudocalanus elongates under laboratory conditions. J. Mar. Biol. Ass. U. K., 48: 97-105.

David T. Morehead, Battaglene, S. C., Metillo, E. B., Brandsen, M. P. and Dunstan, G. A. 2005. Copepod as a live feed for striped trumpeer, Latris lineate larvae. In: Lee, C. S., O'Bryen and Marcus, N. H. (Eds.), Copepods in aquaculture, Blackwell Publishing, USA, p.195-207.

Delbare, D., Dhert, P. and Lavens, P. 1996. Zooplankton In: Lavens, P. and Sorgeloos, P. (Eds.), Manual on the production and use of live food for aquaculture. FAO Fisheries Technical Paper, 361, Rome, Italy, p. 252-282.

Gopakumar, G., Madhu, K., Reeta Jayasankar, Rema Madhu, Kizhakudan, J. K., Josileen, J., Boby Ignatius, Vijayagopal, P., Shoji Joseph, Gulshad, M. and Molly Varghese, 2008. Live feed research for larviculture of marine finfish and shellfish. Mar. Fish.Inf. Ser. T\&E Ser., 197:1-6.

Guisande, C., Sanchez, J., Maneiro, I. and Miranda, A. 1996. Trade off between offspring number and offspring size in the marine copepod Euterpina acutifrons at different food concentrations. Mar. Ecol. Prog. Ser., 143(1-3): 37-44.

Huei-Meei Su, Shin-Hong Cheng, Tzzy-Ing Chen and Mao-Sen $\mathrm{Su} 2005$. Culture of copepods and applications to marine finfish larval rearing in Taiwan. In: Lee, C. S., O'Bryen and Marcus, N. H. (Eds.), Copepods in aquaculture, Blackwell Publishing, USA, p.151-168.

Joebert, D. Toledo, Ma SalvacionGolez and Atsushi Ohno 2005. Studies on the use of copepods in the semi-intensive seed production of grouper Epinephelus coioides. In: Lee, C. S., O'Bryen and Marcus, N. H. (Eds.), Copepods in aquaculture, Blackwell Publishing, USA, p.151-168.

Kraul, S. 1990. Production of live prey for marine fish larvae. Institut. Francais de Recherche Pour I'exploitation de la Mer. Brest., 9: 595-607.

McKinnon, S. Duggan, Nichols P. D., Rimmer, M. A., Semmens, G. and Robino, B. 2003. The potential of tropical paracalanid copepods as live feeds in aquaculture. Aquaculture, 223: 89-106.

Miralto, A., Ianora, A. and Poulet, S. A. 2005. Food type induces different reproductive responses in the copepod Centropages typicus. J. Plankton Res., 17: 1521-1534.

Murray, M. M. and Marcus, N. H. 2002. Survival and diapause egg production of the copepod Centropages hamatus raised on dinoflagellate diets. J. Exp. Mar. Biol. Ecol., 270: 39-56.

Nanton, D. A. and Castell, J. D. 1998. The effects of dietary fatty acids on the fatty acid composition of the harpacticoid copepod, Tisbe sp., for use as a live food for marine fish larvae. Aquaculture, 163: 251-261.

Nassogne, A. 1970. Influence of food organisms on the development and culture of pelagic copepods. Helgolander Wiss. Meeresunters, 20: 333-345.

Payne, M. F. and Rippingale, R. J. 2000. Evaluation of diets for culture of the calanoid copepod Gladioferens imparipes. Aquaculture, 187: 85-96.

Razouls, S., Nival, S. and Nival, P. 1986. Reproduction in Temora stylifera: Anatomic implications in relation to nutritional status. J. Plankton Res., 8(5): 875-889.

Robin, J. Shields, Tomonari Kotani, Augustine Molnar, Kimo Marion, Jon Kobasiwaga and Larren Tang 2005. Intensive cultivation of a subtropical paracalanoid copepod, Parvocalanus sp.: A prey for small marine fish larvae. In: Lee, C. S., O’Bryen and Marcus, N. H. (Eds.), Copepods in aquaculture, Blackwell Publishing, USA, p. 209-223.

Schipp, G. R., Bosmans, J. M. P. and Marshall, A. J. 1999. A method for hatchery cultivation of tropical calanoid copepods, Acartia sp., Aquaculture, 174: 81-88.

Shrivastava, Y., Brenda Fernandes, Goswami, S. C., Usha Goswami and Achuthankutty, C. T. 1999. Observations on feeding behaviour and survival rates in the estuarine calanoid copepod Acartia spinicauda and Helipdiatptomus cinctus 
(Crustacea: Copepoda: Calanoida). Indian J. Mar. Sci., 28: $222-224$

Stottrup, J. G. 2000. The elusive copepods: Their production and suitability in marine aquaculture. J. World Aquac. Soc., 23: $307-316$.

Stottrup, J. G. and Jensen, J. 1990. Influence of algal diet on feeding and egg production of the calanoid copepod, Acartia tonsa Dana. J. Mar. Biol. Ass. U.K., 141: 87-105.

Stottrup, J. G. and Norsker, N. H. 1997. Production and use of copepods in marine fish larviculture. Aquaculture, 155: 231-247.
Sun, B. and Fleeger, J. W. 1995. Sustained mass culture of Amphiasacoides atopus, a marine harpaticoid copepod in a recirculating system. Aquaculture, 136: 313-321.

Turk, P. E., Krejci, M. E. and Yang, W. T. 1982. Laboratory method for the culture of Acartia tonsa (Crustacea: Copepoda) using rice bran. J. Aquac. Aquat. Sci., 3(2): 25-27.

Vilela, M. H. 1992. Mass culture and nutritional quality of the marine copepod Tigriopus brevicornis Mueller. Bol. Inst. Nac. Invest. Pescas. Port., 17: 49-60. 